\title{
Cs Accumulation Behavior by Pseudomonas fluorescens
}

\author{
Atsushi Nakao,,a,b Takahiro Yoshida, ${ }^{\text {b }}$ Takuo Ozaki, ${ }^{\text {b }}$ Toshihiko Ohnuki, ${ }^{b}$ Shinya Funakawa, ${ }^{a}$ and \\ Takashi Kosaki ${ }^{a}$ \\ ${ }^{\mathrm{a}}$ Graduate school of agriculture, Kyoto University, Sakyo-ku, Kyoto 606-8502, Japan \\ ${ }^{\mathrm{b}}$ Advanced Science Research Center, Japan Atomic Energy Research Institute, Tokai, Ibaraki 319-1195, Japan
}

Received: November 15, 2004; In Final Form: April 21, 2005

\begin{abstract}
Cs accumulation by Pseudomonas fluorescens was examined under conditions of growth and resting to elucidate the interaction between Cs and bacteria. In the growth condition, $P$. fluorescens was cultured in citric acid media containing $50 \mu \mathrm{M} \mathrm{CsCl}$ and $0,0.1,1.0$, and $10 \mathrm{mM} \mathrm{K}$ for $64 \mathrm{~h}$ at $30^{\circ} \mathrm{C}$. Adsorption and desorption behaviors of Cs were examined by the contact of the cells with $50 \mu \mathrm{M} \mathrm{CsCl}$ solution under the resting condition. Cs-accumulated $P$. fluorescens was exposed to a $1 \mathrm{M} \mathrm{CH}_{3} \mathrm{COONH}_{4}$ solution to examine the reversibility of Cs accumulation. In the growth condition, $P$. fluorescens did not accumulate $\mathrm{Cs}$ irrespective of the presence of $\mathrm{K}$. In the resting condition, the cells quickly adsorbed approximately $5 \mu \mathrm{mol} \mathrm{Cs} / \mathrm{g}_{\text {cell dry-weight }}$ and subsequently released approximately $90 \%$ of the adsorbed Cs with $1 \mathrm{M} \mathrm{CH}_{3} \mathrm{COONH}_{4}$. The amount of Cs adsorption by cells of $P$. fluorescens varied with changing $\mathrm{pH}$ and ionic strength of the solution. These results indicate that $\mathrm{Cs}$ accumulation by $P$. fluorescens occurs mainly by reversible adsorption on the cell walls, but not by intracellular accumulation under nutrient conditions.
\end{abstract}

\section{Introduction}

Radiocesium $\left({ }^{137} \mathrm{Cs}\right)$ released by nuclear weapons tests and nuclear power plant accidents tends to remain in surface soils for a long period. ${ }^{1,2}$ Cesium-137 in surface soils may be transferred to plants grown in the contaminated soil., 4 Thus, the migration behavior of ${ }^{137} \mathrm{Cs}$ within soils should be elucidated for predicting ${ }^{137} \mathrm{Cs}$ contamination in plants.

Bacteria may have an important role in regulating the transfer of ${ }^{137} \mathrm{Cs}$ from soil to plants, because they have the ability to accumulate metal cations on their cell surfaces and inside their cells. ${ }^{5,6}$ It has been reported that $\mathrm{K}$ concentrations in solution affect the accumulation of Cs by bacteria, and that $\mathrm{K}$ transport systems largely determine the Cs-uptake ability of bacteria. ${ }^{7,8}$ Some bacteria, such as Rhodococcus erythropolis and Escherichia coli, are known to have a specific K transport system (Kup) through which $\mathrm{Cs}$ is transported into cells. $R$. erythropolis has been shown to accumulate less Cs from solutions with higher K concentrations. ${ }^{8}$ Pseudomonas fluorescens, ubiquitous in the terrestrial environment, accumulates negligible amounts of Cs compared to that by these bacteria. ${ }^{7}$ However, the effect of $\mathrm{K}$ on $\mathrm{Cs}$ accumulation by $P$. fluorescens is still unknown.

Bacterial cell surfaces have functional groups, including carboxylic, phosphate, amine, and hydroxyl groups. These surface functional groups are deprotonated with increasing $\mathrm{pH}$ and thus provide the bacteria with a net negative surface charge. ${ }^{10}$ Bacterial cell walls have a high affinity for various metal cations through coordination with these functional groups. ${ }^{5} P$. fluorescens is known to have these functional groups on its cell walls. However, little is known about the interaction between Cs and its cell walls.

The purpose of this study was to investigate the effect of $\mathrm{K}$ on Cs accumulation by $P$. fluorescens, and to elucidate the association of Cs with $P$. fluorescens. The association of Cs with growing cells was investigated in media with $0-10 \mathrm{mM}$ $\mathrm{K}$. Adsorption and desorption experiments were conducted

*Corresponding author. E-mail: na_4_ka@popx.tokai.jaeri.go.jp FAX: +81-29-282-5927. using resting cells at pHs $3.0-9.0$ and $1.0-100 \mathrm{mM} \mathrm{NaCl}$ at $\mathrm{pH} 6.0$, and the time course of Cs adsorption and desorption was measured.

\section{Materials and Methods}

Associations of Cs with growing cells. We used $P$. fluorescens (ATCC 55241) that was isolated from a low-level radionuclides waste disposal site at West Valley, New York. ${ }^{11}$ $P$. fluorescens was pre-cultured at $30{ }^{\circ} \mathrm{C}$ for $24 \mathrm{~h}$ in $50 \mathrm{~mL}$ of culture media containing $1 \mathrm{mM} \mathrm{KCl}, 10 \mathrm{mM}$ citric acid, $0.1 \mathrm{M}$ $\mathrm{NaCl}, 6.7 \mathrm{mM}\left(\mathrm{NH}_{4}\right)_{2} \mathrm{SO}_{4}, 10 \mathrm{mM} \mathrm{Na} \mathrm{HPO}_{4}$, and $10 \mathrm{mM}$ 4-(2hydroxyethyl)-1-piperazineethanesulfonic acid (HEPES). The $\mathrm{pH}$ of the medium was adjusted to 6.0 before autoclaving at $120^{\circ} \mathrm{C}$ for $20 \mathrm{~min}$.

The pre-cultured cell suspensions were inoculated into 50 $\mathrm{mL}$ culture media containing $0,0.1,1.0$ or $10 \mathrm{mM} \mathrm{KCl}, 50 \mu \mathrm{M}$ $\mathrm{CsCl}, 10 \mathrm{mM}$ citric acid, $0.1 \mathrm{M} \mathrm{NaCl}, 6.7 \mathrm{mM}\left(\mathrm{NH}_{4}\right)_{2} \mathrm{SO}_{4}, 10$ $\mathrm{mM} \mathrm{Na}_{2} \mathrm{HPO}_{4}$, and $10 \mathrm{mM}$ HEPES; then, these cultures were allowed to stand at $30{ }^{\circ} \mathrm{C}$. Five milliliters of the cell suspension was withdrawn at $18,30,42$, and $64 \mathrm{~h}$ after inoculation. Cell growth was determined on the basis of the optical density of the culture medium measured at $600 \mathrm{~nm}(\mathrm{OD})$. The concentration of citric acid was measured by high-pressure liquid chromatography-mass spectroscopy (HPLC-MS) (Alliance 2695, Waters Corporation, Milford, MA, USA). The Cs concentration was measured by a model AA6200 atomic absorption spectrophotometer (AAS) (Shimadzu Co., Kyoto, Japan).

Cs adsorption on and desorption from resting cells. Pseudomonas fluorescens cells grown in a beef-extract solution ( $3 \mathrm{~g} \mathrm{~L}^{-1}$ beef extract, $5 \mathrm{~g} \mathrm{~L}^{-1}$ polypepton, and $5 \mathrm{~g} \mathrm{~L}^{-1} \mathrm{NaCl}$ ) were used for the adsorption and desorption experiment. Cells were harvested by centrifugation at $4000 \mathrm{rpm}$ for $10 \mathrm{~min}$. The cell pellet was washed three times with a $10 \mathrm{mM} \mathrm{NaCl}$ solution, and cells were resuspended in a $10 \mathrm{mM} \mathrm{NaCl}$ solution to obtain a $20 \mathrm{mg} \mathrm{mL}^{-1}$ cell suspension on a dry weight basis.

In adsorption experiments, $20 \mathrm{mg}$ of the cell pellet was combined with $10 \mathrm{~mL}$ of a $50 \mu \mathrm{M} \mathrm{CsCl}$ solution containing 10 $\mathrm{mM} \mathrm{NaCl}$. In order to examine the time course of the Cs adsorption, cells were maintained with $\mathrm{Cs}$ at $\mathrm{pH} 7.0$ for $0.5,3$, 
12, and $24 \mathrm{~h}$. In order to examine the effect of $\mathrm{pH}$ and ionic strength on the Cs adsorption by $P$. fluorescens, cells were also maintained with $\mathrm{Cs}$ at $\mathrm{pHs} 3.0,7.0$, and 9.0 and in 1, 10, and $100 \mathrm{mM} \mathrm{NaCl}$ for $12 \mathrm{~h}$. After the controlled contact, supernatants were separated from the cells by centrifugation at 4000 rpm for $10 \mathrm{~min}$. The Cs concentration in the supernatant was measured by AAS.

The cells maintained with the Cs solution containing $10 \mathrm{mM}$ $\mathrm{NaCl}$ at $\mathrm{pH} 7.0$ for $12 \mathrm{~h}$ were used for desorption experiments after washing the cells once with distilled water at $\mathrm{pH} 6.8$ and collecting them by centrifugation at $4000 \mathrm{rpm}$ for $10 \mathrm{~min}$. The collected cells were resuspended in a $1 \mathrm{M} \mathrm{CH}_{3} \mathrm{COONH}_{4}$ solution for $3,12,24$, and $36 \mathrm{~h}$. The suspensions were centrifuged at $4000 \mathrm{rpm}$ for $10 \mathrm{~min}$. The Cs concentrations in the supernatants were measured by AAS.

\section{Results and Discussions}

Growth of $\boldsymbol{P}$. fluorescens and its association with Cs. Figures $1 \mathrm{a}$ and $1 \mathrm{~b}$ show the time courses of the OD and the citric acid concentration, respectively, in the media containing different $\mathrm{Cs}$ concentrations after the inoculation of $P$. fluorescens. In the absence of $\mathrm{K}$, the $\mathrm{OD}$ did not increase and the concentration of citric acid slightly decreased from $20 \mathrm{mM}$ to $17 \mathrm{mM}$ over $64 \mathrm{~h}$. These results indicate that $P$. fluorescens cells did not grow in the absence of $\mathrm{K}$.

In the medium containing $0.1 \mathrm{mM} \mathrm{KCl}$, the OD increased gradually to 0.28 and the citric acid concentration decreased to $0.23 \mathrm{mM}$ for $64 \mathrm{~h}$. In the media containing 1.0 and $10 \mathrm{mM}$ $\mathrm{KCl}$, the OD increased to 0.58 and 0.60 , respectively, for $42 \mathrm{~h}$, when the citric acid concentration decreased to below the detection limit, and then gradually decreased through $64 \mathrm{~h}$. These results indicate that the cell growth was influenced by K in the medium. The growth of Rhodopseudomonas capsulata cells is enhanced by 0.1 and $1.0 \mathrm{mM}$ Cs even in the absence of K. $R$. capsulata has a specific $\mathrm{K}$ transporter (i.e. Kup), which shows low selectivity between $\mathrm{K}$ and Cs. ${ }^{12}$ However, in this
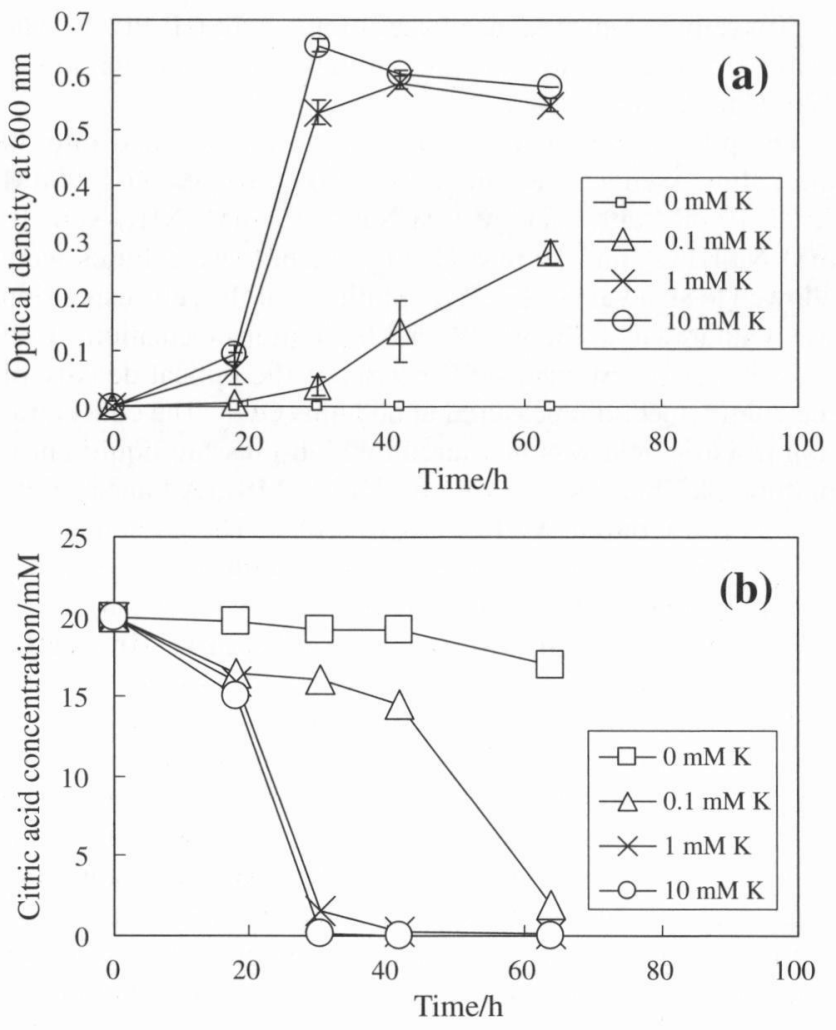

Figure 1. Time-course of the (a) OD and (b) citric acid concentrations (mM) in medium solutions containing Cs of $50 \mu \mathrm{M}$ and $\mathrm{K}$ of 0 , $0.1,1.0$, or $10 \mathrm{mM}$ after the inoculation of P. fluorescens. The bars show the standard deviation for triplicate measurements of individual $\mathrm{K}$ concentrations. study, the presence of $\mathrm{Cs}$ without $\mathrm{K}$ did not result in the growth of $P$. fluorescens cells.

Figure 2 shows the time-course of the accumulation of $\mathrm{Cs}$ by $P$. fluorescens, which was calculated from the reduction of Cs concentration in medium solutions. In the media with different $\mathrm{K}$ concentration, Cs accumulation was not shown and there was little effect of the difference of $\mathrm{K}$ on the Cs accumulation by $P$. fluorescens during the growth period. It has been reported that $\mathrm{Cs}$ is transported into bacterial cells in the same way as $\mathrm{K}$ to some degree, because of their similar chemical properties. $^{12,13}$ Tomioka et al. $^{7}$ showed that Cs was not accumulated by $P$. fluorescens in the medium containing $\mathrm{K}$ as a constituent of an yeast extract medium. In the present study, we revealed that $\mathrm{Cs}$ was not accumulated by $P$. fluorescens in the culture media containing $0-10 \mathrm{mM} \mathrm{K}$. This suggested that $P$. fluorescens selectively transported $\mathrm{K}$ into the cells against $\mathrm{Cs}$ and that $\mathrm{Cs}$ did not function in place of $\mathrm{K}$ for the growth of P. fluorescens.

Adsorption and desorption of Cs under resting conditions. The time course of the adsorption of Cs on P. fluorescens at resting conditions (Figure 3 ) showed that the amount adsorbed reached approximately $5.0 \mu \mathrm{mol} \mathrm{Cs} / \mathrm{g}_{\text {cell }}$ dry-weight at $30 \mathrm{~min}$, and then remained constant up to $24 \mathrm{~h}$. The $\mathrm{pHs}$ of the solutions were between 6.6 and 7.0 during the experiment. Note that the amount of cell pellet in contact with Cs solutions was approximately 10 times higher than the maximum amount obtained in the growth experiment. The rapid adsorption of metals on bacterial cells has been widely reported. ${ }^{14,15}$

The amount of Cs accumulated increased from 1.8 to 4.2 $\mu \mathrm{mol} \mathrm{Cs} / \mathrm{g}_{\text {cell }}$ dry-weight with a rise in the $\mathrm{pH}$ of the solution from 3.5 to 7.5 (Figure 4). The final $\mathrm{pHs}$ were $3.5,6.7$, and 7.5 , changing variously from their starting values of 3.0, 7.0, and 9.0 , respectively. The $P$. fluorescens cells have carboxyl and phosphate functional groups on their surfaces. ${ }^{16}$ These func-

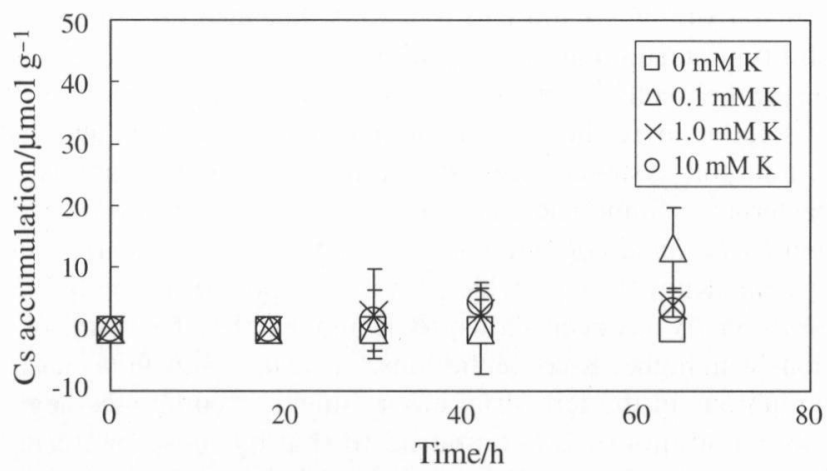

Figure 2. Time-course of the accumulation of Cs by $P$. fluorescens during the growth of the cells, which was calculated from the reduction of Cs concentration in the growth media. The sampling sets were in triplicates.

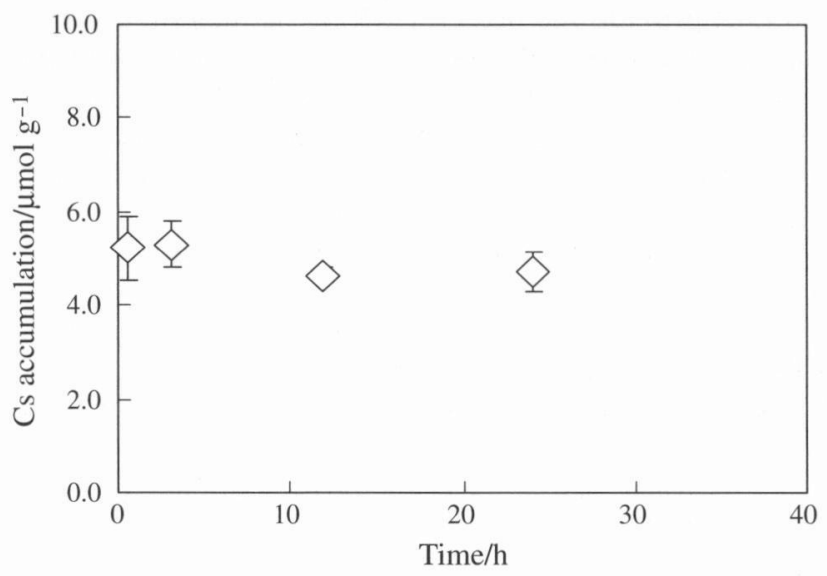

Figure 3. Time-course of Cs concentration adsorbed on the cells of $P$. fluorescens after exposure to a $50 \mu \mathrm{M} \mathrm{CsCl}$ solution of $10 \mathrm{~mL}$. 


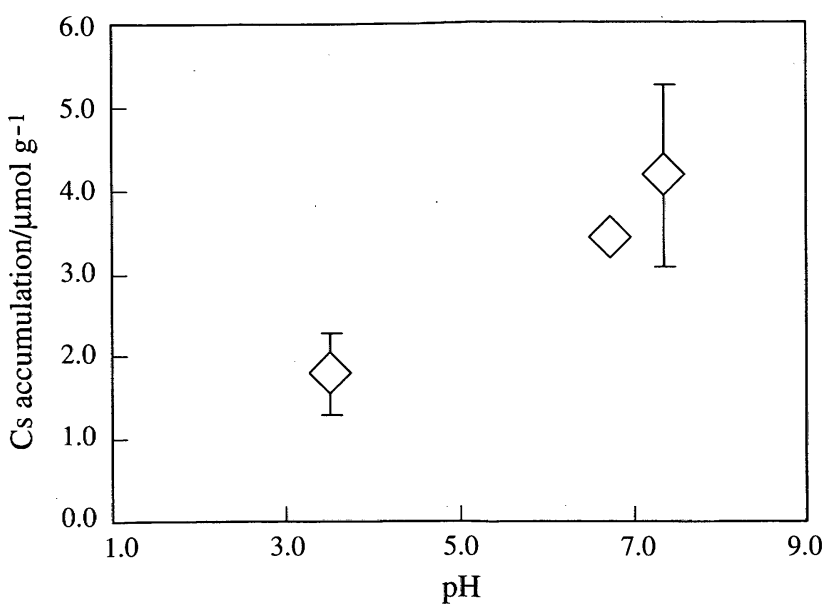

Figure 4. Effect of $\mathrm{pH}$ on the accumulation of $\mathrm{Cs}$ by $P$. fluorescens cells. The final pHs are shown in the figure.

tional groups deprotonate with increasing $\mathrm{pH}$ and consequently associate with cations. ${ }^{10}$ The $\mathrm{pH}$ dependence in the Cs adsorption showed that the adsorption of Cs occurred through the exchange with $\mathrm{H}^{+}$on functional groups of the cell surfaces of $P$. fluorescens.

Figure 5 shows Cs accumulation by $P$. fluorescens cells at 1 , 10 , and $100 \mathrm{mM} \mathrm{NaCl}$ at $\mathrm{pH} 6.9 \pm 0.1$. The amount of the Cs accumulated was $4.5,3.0$, and $1.9 \mu \mathrm{mol} \mathrm{Cs} / \mathrm{g}_{\text {cell dry-weight }}$ at 1.0 , 10 , and $100 \mathrm{mM} \mathrm{NaCl}$, respectively. The decrease in the amount of $\mathrm{Cs}$ accumulation with increasing $\mathrm{Na}$ concentration results from competition in the adsorption of $\mathrm{Cs}$ and $\mathrm{Na}$ by the functional groups of the cell surfaces. Intracellular Cs accumulation through $\mathrm{Na}$ transport channels is unlikely to occur because no Cs was accumulated under the growing condition (Figure 2).

The time course of the desorption of Cs from the Cs accumulated P. fluorescens at $\mathrm{pH} 7.0$ for $12 \mathrm{~h}$ (Figure 6) showed that the adsorbed $\mathrm{Cs}$ was almost completely desorbed within $24 \mathrm{~h}$ by $1 \mathrm{M} \mathrm{CH}_{3} \mathrm{COONH}_{4}$. A $1 \mathrm{M} \mathrm{CH}_{3} \mathrm{COONH}_{4}$ solution is typically used as an extract solution to estimate the amount of the reversible cations in soils. ${ }^{17}$ Thus, Cs is reversibly adsorbed on the functional groups of the cell surfaces of $P$. fluorescens. The Cs desorption rate was slower than the Cs adsorption rate. Ohnuki and Kozai ${ }^{18}$ reported that the desorption and the adsorption rates were almost equivalent in the case of smectite. $P$. fluorescens has peptidoglycan layers on its cell walls, which consist of a cross-linked mesh structure. ${ }^{19}$ The results suggest that adsorption of Cs on the cell surfaces of $P$. fluorescens differs from that on the reversible site in smectite.

Oughton et al. ${ }^{20}$ reported that approximately $10 \%$ of radiocesium was extracted with $1 \mathrm{M} \mathrm{CH}_{3} \mathrm{COONH}_{4}$ from contaminated soils collected at 3 places in the $30 \mathrm{~km}$ exclusion zone surrounding the Chernobyl reactors. Even with a heated and consequently highly reactive acid solution $\left(\mathrm{pH} 2.0,80^{\circ} \mathrm{C}\right)$, more than $60 \%$ of the radiocesium could not be extracted. ${ }^{20}$ The Cs fixation in soils can be explained as an irreversible adsorption of $\mathrm{Cs}$ on micaceous clays through the formation of inner-sphere complexes. ${ }^{21,22}$ On the other hand, it was reported that Cs fixation on clay minerals was reduced by adding humic substances because of a decrease in the average affinity of the cation adsorption sites of Cs. ${ }^{23}$ It is well known that reversible cations in the adsorption phase are available to plants. Our results suggest that Cs adsorption on the bacterial cell surfaces of $P$. fluorescens plays a less important role in restricting the migration of $\mathrm{Cs}$ than micaceous clays but might enhance the plant availability of Cs, because Cs was adsorbed on the bacterial cells reversibly.

No investigation has been conducted on preferential adsorption of Cs between micaceous clays and $P$. fluorescens. $P$. fluorescens releases strong chelate reagents (i.e. siderophore), ${ }^{24}$

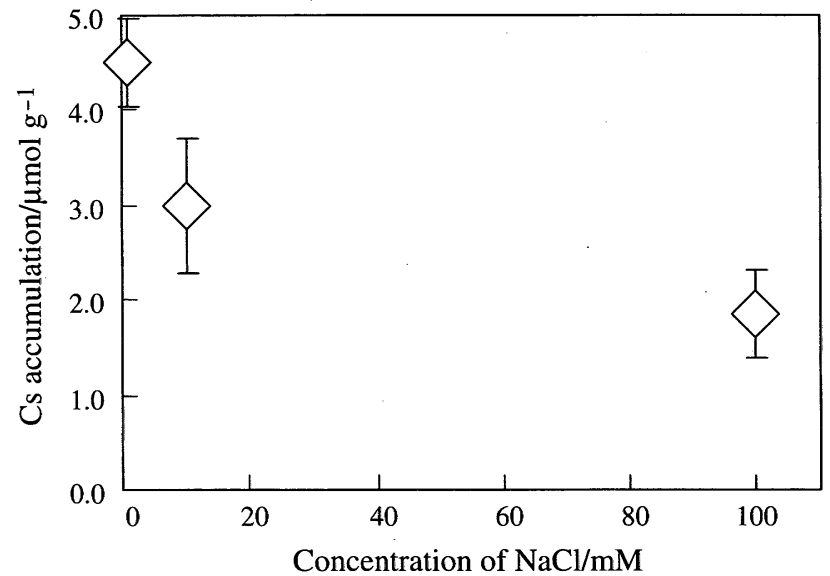

Figure 5. Effect of the $\mathrm{NaCl}$ concentration on the accumulation of $\mathrm{Cs}$ by $P$. fluorescens cells.

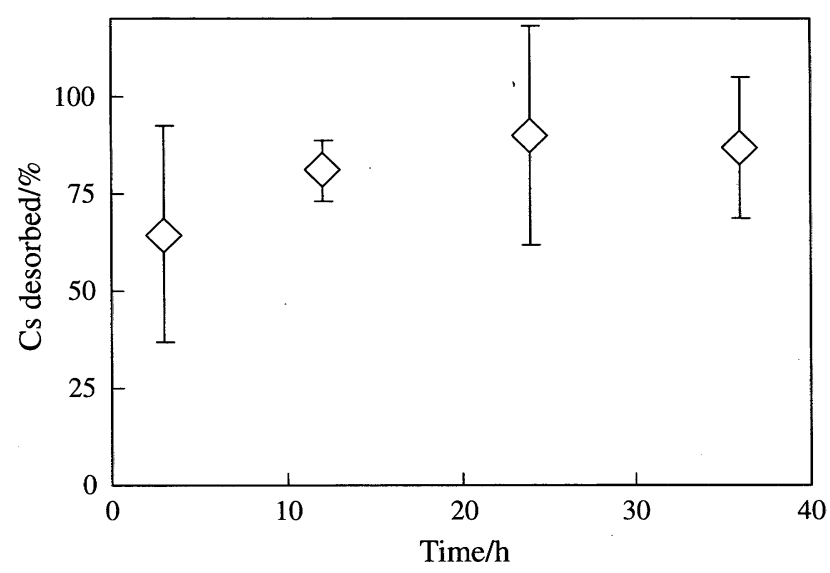

Figure 6. Time-course of the Cs concentration desorbed from cells of $P$. fluorescens by a $1 \mathrm{M} \mathrm{CH}_{3} \mathrm{COONH}_{4}$ solution. The $\mathrm{Cs}$ fraction was defined to be $100 \%$ when all the adsorbed Cs was desorbed.

which may enhance Cs desorption from micaceous clays by dissolving the inner-sphere structure complexes. Even though $P$. fluorescens accumulated only a small amount of Cs, further investigation should be performed to elucidate the effects of bacteria on the migration behavior of Cs in soils.

\section{References}

(1) Bossew, M. Gastberger, H. Gohla, P. Hofer, and A. Hubmer, J. Environ. Radioactiv. 73, 97 (2004).

(2) B. Salbu, D. H. Oughton, A. V. Rantnikov, T. L. Zhigareva, S. V. Kruglov, K. V. Petrov, N. V. Grebenshakikova, S. K. Firsakova, N. P. Astasheva, N. A. Loshchilov, K. Hove, and P. Strand, Health Phys. 67, 518 (1994).

(3) Y.G. Zhu and E. Smolders, J. Exp. Bot. 51, 1635 (2000).

(4) H. Tsukada and Y. Nakamura, Sci. Total Environ. 228, 111 (1999).

(5) T. J. Beveridge and S. F. Koval, Appl. Environ. Microbiol. 42, 325 (1992).

(6) S. Silver and M. Walderhaug, Microbiol. Rev. 195 (1992).

(7) N. Tomioka, H. Uchiyama, and O. Yagi, Appl. Environ. Microbiol. 58, 1019 (1992).

(8) N. Tomioka, H. Uchiyama, and O. Yagi, Appl. Environ. Micobiol. 60, 2227 (1994).

(9) D. Bossemeyer, A. Schrosser, and E.P. Bakker, J. Bacteriol. 171, 2219 (1989).

(10) V. R. Phoenix, R. E. Martinez, K. O. Konhauser, and F. G. Ferris, Appl. Environ. Microbiol. 68, 4827 (2002).

(11) A. J. Francis, C. J. Dodge, and J. B. Gillow, Nature 356, 140 (1992).

(12)P. Jasper, J. Bacteriol. 133, 1314 (1978). 
(13) S. V. Avery, J. Ind. Microbiol. 14, 76 (1995).

(14)E. S. Cossich, C. R. G. Tavares, and T. M. K. Ravagnani, Electron. J. Biotechnol. 5, 133 (2002).

(15) T. Ozaki, J. B. Gillow, T. Kimura, T. Ohnuki, Z. Yoshida, and A. J. Francis, Radiochim. Acta 92, 741 (2004).

(16) T. Yoshida, T. Ozaki, T. Ohnuki, and A. J. Francis, (submitted).

(17) C. J. Schollenberger and R. H Simon, Soil Sci. 59, 13 (1945).

(18) T. Ohnuki and N. Kozai, Radiochim. Acta 66/67, 327 (1994).

(19) T. J. Beveridge and S. F. Koval, Appl. Environ. Microbiol. 42, 325 (1981).

(20) D. H. Oughton, B. Salbu, G. Riise, H. Lien, G. Ostby, and
A. Noren, Analyst 117, 481 (1992).

(21) A. B. Hird, D. L. Rimmer, and F. R. Livens, Eur. J. Soil Sci. 47, 97 (1996).

(22) B. C. Bostick, M. A. Vairavamurty, K. G. Kartyikeyan, and J. Chorover, Environ. Sci. Technol. 36, 2670 (2002).

(23) C. Dumat and S. Staunton, J. Environ. Radioactiv. 46, 187 (1999).

(24) D. Mossialos, J. M. Meyer, H. Budzikiewick, U. Wolff, N. Koedam, C. Baysse, V. Anjaiah, and P. Cornelis, Appl. Environ. Microbiol. 66, 487 (2000). 